\title{
Comparison of two methods for evaluating waste of a flow through trout farm
}

\author{
Emmanuelle Roque d'Orbcastel ${ }^{a,{ }^{*}}$, Jean-Paul Blancheton ${ }^{a,{ }^{*}}$, Thierry Boujard ${ }^{b}$, Joël Aubin $^{c}$, \\ Yves Moutounet $^{d}$, Cyrille Przybyla ${ }^{a}$ and Alain Belaud ${ }^{\mathrm{e}}$
}

\footnotetext{
a IFREMER, Station d'Aquaculture Expérimentale, Laboratoire de Recherche Piscicole de Méditerranée. Chemin de Maguelone, 34250 Palavas-les-Flots, France

b INRA, Unité mixte INRA/IFREMER, Equipe Nutrition Aquaculture et Environnement. Station INRA, 64310 Saint Pée sur Nivelle, France

c INRA, UMR SAS, Equipe Fields, 65 rue de St Brieuc, 35042 Rennes cedex, France

d BIOMAR S.A., Z.I. de Nersac, 16440 Nersac, France

e ENSAT, Ecole Nationale Supérieure d'Agronomie de Toulouse, Avenue de l'Agrobiopole, Auzeville Tolosane, 31326 Castanet Tolosan, France
}

*: Corresponding author: E. Roque, J.P. Blancheton, Tel.: +33 4671304 12; fax: +33 4671304 58, email address : Jean.Paul.Blancheton@ifremer.fr, Emmanuelle.Roque@ifremer.fr

\begin{abstract}
:
European water legislation enforces increasingly restrictive measures with regards to reduction of water consumption and waste emission in order to minimise the potential environmental impact of the agro industry sector. Fish farms are particularly concerned, but legislation covering effluent discharge varies significantly from country to country. However, recommendations and directives from institutional, national or regional bodies suggest the enforcement of increasingly strict waste reduction measures and the development of waste treatment. Before treatment, it is necessary to evaluate waste production in terms of composition and quantity. The waste quantification methods used today for fish culture systems are either based on direct measurements of nutrient and suspended solid fluxes or on indirect evaluation based on the digestibility coefficients of the feed constituents. The objective of the present study is to evaluate the waste of a freshwater flow through farm using both approaches and to discuss their applicability, drawbacks and advantages from the viewpoints of fish farmers and control authorities. Waste production on the farm was monitored during several 24 hour cycles in order to characterise the effluents of the system. The predictions and measurements for the total nitrogen (TN) parameter were well correlated, but measured and predicted suspended solids (SS) and total phosphorus (TP) values presented a weaker correlation coefficient. The hydrobiological method gives details on the $\mathrm{N}$ and $\mathrm{P}$ forms of waste but this method is heavy and it is difficult to obtain representative samples and flow rate measurements. The nutritional method is the simplest to use, provided that feed data are available.
\end{abstract}

Keywords: Waste; Trout farm; Suspended solids; Nitrogen; Phosphorus 


\section{Introduction}

26 There are large differences in aquaculture regulations, in waste control and water quality

27 survey methods and in legislation between European countries. In most countries, water

28 quality is monitored by competent authorities and/or by self-monitoring (Fernandes et al.,

29 2000; Bergheim and Brinker, 2003). Most countries have environmental quality standards

30 mainly in relation to water quality and nutrient release. Some, such as Ireland or Norway,

31 have brought in farming limitations based on a maximal stocking density or a maximal yearly

32 feed quantity (Maroni, 2000). The aim of the EC Water Framework Directive (2000/60) is to

33 develop a sustainable policy for environmental protection and especially, to homogenize all

34 the directives or Community decisions adopted since 1975 on the fight against pollution and

35 on the definition of water quality standards. Countries must progressively reduce polluted

36 water emissions and develop monitoring programs with a view to improving water quality

37 before 2015.

38 Concerning fish farm waste regulations, one may distinguish two different approaches: one

39 based on a maximal authorized feed quantity; the other on maximal authorized emissions in

40 the recipient ecosystem. In Denmark for example, the Danish decree (2002, November, $\left.8^{\text {th }}\right)$

41 fixed: (1) a maximal authorized annual feed quantity for freshwater farms, reduced or

42 increased depending on water abundance and natural quantity and on the effluent treatment

43 system, and (2) feed composition (energy, N, P and ash). A limit has been set on the tonnage

44 of total nitrogen and phosphorous released into marine waters also (Pedersen, 1999). In

45 France, the "polluter payer" principle implies that fish farmers must pay a tax to the regional

46 water agencies. The payment is calculated on annual feed quantity and suspended solids (SS),

47 nitrogen $(\mathrm{N})$ and phosphorous $(\mathrm{P})$ fluxes, with global emission coefficients obtained from

48 feed digestibility determinations. Fish farm effluents are also regulated by the French ICPE 
49 legislation (Classified Installations for the Protection of the Environment) ${ }^{1}$. This concerns

50 fresh water farms and seawater farms with annual production above 10 metric tons and 20

51 tons respectively. The key element of this legislation is the environmental impact assessment,

52 in which waste quantification is required, and its impact evaluated. Therefore, in view of

53 water legislation changes, fish waste characterisation and quantification are both key elements

54 for fish farm operations and their waste monitoring and treatment.

55 For this purpose one may consider the particularities and origin of the wastes. Typically, fish

56 waste is characterised by its high level of dilution when compared to other animal production

57 or industrial wastewaters. The wastes first originate from the partial intake by fish or the

58 partial digestibility of feed. When feed is metabolised by fish for energy and growth

59 (including gamete production), as the efficiency of any biological reaction is less than 100\%,

60 some catabolites are produced in solid and soluble forms. Solid wastes, comprising faecal

61 matter, constitute a more or less compact settlable material. Their chemical composition $(\mathrm{C}$,

$62 \mathrm{~N}, \mathrm{P}$ ) and physical characteristics (size, density, water content...) depend on the feed

63 composition and on the fish (species, phase of development). Large variations in nutrient

64 utilisation by fish have been reported, depending on the type of nutrient (Kaushik, 1998). In

65 addition to solids, faeces contain water and dissolved substances, mainly phosphorus and

66 calcium. Fish also excrete soluble compounds through the gills and kidneys. When lipid and

67 carbohydrate degradation produce $\mathrm{CO}_{2}$ and water, protein degradation mainly produces

68 ammonia $\left(\mathrm{NH}_{3}\right.$ and $\left.\mathrm{NH}_{4}{ }^{+}\right)$, representing 80 to $90 \%$ of the soluble nitrogen excreted, with the

69 balance being excreted mostly as urea. For most of the fish, nitrogen excretion represents 50

70 to $70 \%$ of the nitrogen intake (Dosdat 1992a, b; Dosdat et al., 1996; Company et al., 1999).

\footnotetext{
${ }^{1}$ Law No. 76-663 of July 19, 1976 with its decree of application No. 77-1133 of September 21, 1977. ICPE law has been codified in 2000 by the Environmental Code; the law is now abrogated and Book $\mathrm{V}$ Title $1^{\text {st }}$ of the Environmental Code is the reference.
} 
71 The main soluble phosphorus waste is orthophosphate $\left(\mathrm{PO}_{4}{ }^{3-}\right)$, representing only about $20 \%$

72 of the phosphorus intake (Dosdat et al., 1996).

73 According to these characteristics, two different methods are used for fish culture systems: (1)

74 a direct method, measuring dissolved and suspended matter in situ fluxes released by the

75 farm, based on a hydrobiological approach and (2) an indirect evaluation, based on a 76 nutritional approach, using defined feed amounts and appropriate digestibility coefficients

77 (Jatteau, 1999).

78 In France, an expert panel ${ }^{2}$ was appointed by the authorities to review the current strategies

79 for evaluation of fish farm wastes (Papatryphon et al., 2005). It was agreed that the method

80 currently in use in France (Fauré, 1983) was not accurate enough and therefore should be

81 replaced. This method uses the following equations to calculate waste production from

82 salmonids :

83 (1) $\mathrm{NH}_{4}\left(\mathrm{~kg} \cdot \mathrm{d}^{-1}\right)=\mathrm{K} *$ alpha $* \mathrm{~A}$, where $\mathrm{K}$ is a coefficient taking into account the 84 number of previous water utilization (n) with $\mathrm{K}=0.8+0.2 * \mathrm{n}$, A is the daily quantity of feed 85 distributed $\left(\mathrm{kg} \cdot \mathrm{d}^{-1}\right)$, and alpha the $\mathrm{NH}_{4}$ production rate.

(2) $\mathrm{SS}\left(\mathrm{kg} \cdot \mathrm{d}^{-1}\right)=(1-\mathrm{Kd})(33 * \mathrm{IC}-20) * \mathrm{~A} / 100$, where $\mathrm{Kd}$ is the fish farm

87 decantation coefficient and IC is the feed conversion ratio.

(3) $\mathrm{TP}\left(\mathrm{kg} \cdot \mathrm{d}^{-1}\right)=0.0048 * \mathrm{~A}$.

89 The expert panel recommended a nutrient-balance model based on work by Cho et al. (1991),

90 Cho and Bureau (1998) and Kaushik (1980, 1998). They carried out an initial validation of

91 the model using data collected in 19 farms (self monitoring data and punctual measurements).

92 This approach is based on the evaluation of the fish waste production through the digestibility

\footnotetext{
2 including scientists and representatives from (1) the French National Institute for Agricultural Research (INRA), the French Research Institute for the Exploitation of the Sea (IFREMER), (2) the feed manufacturing sectors, (3) the French Aquaculture Federation (FFA) and the Inter-Professional Committee of Aquaculture Products (CIPA)
} 
93 of the distributed feed: waste production is given by the difference between the quantity of

94 nutrient ingested and the part kept by the fish for its body gain.

95 The hydrobiological approach is based on the water flow rates and concentrations measured at

96 the inlet and the outlet of the fish farm. Dissolved and particulate fluxes are calculated by

97 subtracting the inlet flow from the outlet flow (Liao, 1970 and Liao and Mayo, 1974). Several

98 studies were carried out (Fauré, 1983; Tarazona et al., 1993, Kelly et al., 1994; Lemarié et al.,

99 1998), but the results were established for few fish species and feed compositions, while

100 composition and digestibility coefficients change over time.

101 Boujard et al. (1999) compared the results of waste evaluation using the nutritional and

102 hydrobiological approaches on several rainbow trout breeding tanks. Nutrient concentrations

103 and flow rate measurements were carried out two times, during two consecutive days, with

104 water sampling and flow rate measurements every two hours. Water sampling and flow rate

105 measurements methods are not described in the publication. Good correlations between

106 measured and predicted values were found, but they found that the predicted values were

107 always underestimated. Papatryphon et al. (2005) compared values predicted by a nutrient-

108 balance model with fluxes calculated from nutrient concentrations measured in the recipient

109 river. The water flow rates and nutrient concentrations were not directly measured during the

110 study but were collected from farmers or water agency records. They found a good

111 correlation, but a tendency to overestimate the predicted $\mathrm{NH}_{4}{ }^{+}$and $\mathrm{P}$ values.

112 This approaches raise the problem of (1) synchronization between nutrient concentrations and

113 flow rate measurements and (2) the accuracy of the water flow rates and nutrient

114 concentration measurements, which are the two key elements to evaluate waste fluxes.

115 In this study, in order to optimise the accuracy on the mass balance evaluation, our approach

116 consisted in simultaneous measurements of nutrient concentrations and flow rates, 4 times

117 during $24 \mathrm{~h}$ periods, using the same methodology and measurements devices located at the 
118 same sampling spots. Continuous data acquisition equipment was used in order to optimise

119 the precision of the measurements.

120 The first objective of our study was to compare the nutrient fluxes obtained using both current

121 approaches in order to evaluate the waste produced by a whole flow through farm, with

122 continuous sampling during several 24 hour periods in order to characterise the daily waste

123 fluxes.

124 The second objective was to discuss the applicability of both waste evaluation approaches for

125 the fish farmers and control authorities, as tools for the waste quantification which is required

126 in the French ICPE legislation.

\section{Materials and methods}

129 The investigation took place in 2005-2006 on the on-growing unit of the Charles Murgat SA

130 trout farm, located at Beaurepaire in south east France. The farm is operated using the flow

131 through system and produces on average 600 tons of brook trout, brown trout, rainbow trout

132 and arctic char per year, at a fish stocking density of around $58 \mathrm{~kg} . \mathrm{m}^{-3}$.

133 The on-growing unit is divided into two sectors (figure 1):

$134 \quad-\quad$ sector 1 is composed of 7 concrete raceways (each $70 * 6 * 0.8 \mathrm{~m}$ ), with 4 species reared

135 from $50 \mathrm{~g}$ to more than $2000 \mathrm{~g}$. Each tank is divided into batches, each comprising

136 different species, at different sizes, corresponding to the market demand. During the

137 studied period, 55 to $70 \%$ of the fish weighed around $200 \mathrm{~g}$ and the average feed

138 conversion ratio (FCR) was 0.85 .

139 - sector 2 is composed of 2 concrete raceways, with only rainbow trout species (from

$200 \mathrm{~g}$ to $1000 \mathrm{~g}$,). The average weight of $50 \%$ of the population is around $500 \mathrm{~g}$ and

141 the average FCR is 0.95 . 
142 Both sectors use very high quality, constant temperature well water (around $10{ }^{\circ} \mathrm{C}$ during the

143 period). The first three tanks of sector 1 are fed with a well water flow rate varying from 600

$1441 . \mathrm{s}^{-1}$ up to $20001 . \mathrm{s}^{-1}$, corresponding to a water renewal rate of between $200 \%$ and $600 \%$ per

145 hour in the tanks. After a first use, the rearing water is filtered through a mechanical filter,

146 oxygenated, and reused in the four following tanks of the sector 1. Each tank is equipped with

147 several aerators in order to keep the oxygen concentration above $5 \mathrm{mg} \mathrm{O}_{2} \cdot 1^{-1}$ in the tank outlet.

148 The effluent of that sector is filtered with another drum filter before being released into the

149 river through a sport fishing area. The two tanks of sector 2 are fed with the same well water,

150 with a flow rate varying around $500 \mathrm{~L} \cdot \mathrm{s}^{-1}$.

151 In this study the wastes produced by the two on-growing units (sectors 1 and 2) of the farm

152 were evaluated using the hydrobiological and the nutritional methods.

153 The "hydrobiological" method

154 The hydrobiological method is based on water sampling and flow rate measurements. In order 155 to optimise the accuracy of the flow rate measurement, it was decided to measure the water 156 velocity in the tanks which are easily accessible, have a well defined cross section) and a 157 more homogeneous hydraulic regime than the water inlet and outlet channels. Four $24 \mathrm{~h}$ 158 sampling periods were performed on sectors 1 and 2 between January and March 2006, the

159 last one only on sector 1 (sector 2 was not sampled because of important fishing events). The 160 sampling period was fixed for $24 \mathrm{~h}$ because the feeding ratio is stable over a period of two 161 days. The inlet and the outlet waters of the two sectors were sampled by ISCO 6712 162 automatic sampler over $24 \mathrm{~h}$, with a frequency of one sample every 30 minutes in order to 163 follow the daily fluctuations of waste concentrations linked to the feeding periods (Hennessy 164 et al, 1996). Water samples were stored 24 hours at $4^{\circ} \mathrm{C}$ before analysis. In water samples, 165 dissolved $\mathrm{N}$ and $\mathrm{P}$, particulate $\mathrm{N}$ and total $\mathrm{P}$ and suspended solids concentrations were 166 measured. 
167 Dissolved $\mathrm{N}$ and $\mathrm{P}$ were measured by spectrophotometry, after filtration on Whatman GF/C

168 filters. $\mathrm{NH}_{4}-\mathrm{N}, \mathrm{NO}_{2}-\mathrm{N}$, urea-N, $\mathrm{PO}_{4}-\mathrm{P}$ were analysed using an Alliance Instruments Evolution

169 II, after AFNOR method (NF T 90-015) described by Solorzano (1969) and the ISO method

170 (6777-1984 F) described by Bendschneider and Robinson (1952) respectively. $\mathrm{NO}_{3}-\mathrm{N}$ was

171 measured with a Technicon ${ }^{\circledR}$ Autoanalyzer II, after a nitrite reduction on a cadmium-copper

172 column (Wood et al., 1967).

173 Particulate-N was obtained after a CHN analysis and total-P by using a colorimetric method

174 NFENISO11885 (after mineralisation). Total $\mathrm{N}$ was calculated by adding the nitrogenous

175 compound concentrations. Suspended solid (SS) concentrations were determined after GF/C

176 filtration (NFEN872).

177 During the sampling periods, the water flow rates were measured with a bottom mounted

178 Argonaut- shallow water Doppler current meter (Huhta and Ward, 2003). This current meter

179 provides a vertically integrated velocity measurement (4 points of measurement in the water

180 column). The water flow rates were measured in the 9 tanks of the farm, which constitute the

181 two sectors, with a frequency of one sample every 15 seconds. The current meter was placed

182 on the bottom of the tanks and moved at different distances of the vertical walls (every $50 \mathrm{~cm}$ )

183 during the 24 hour period. These measures enabled calculation of the average water flow rate

184 of the farm. The effluent (dissolved, particulate and SS) fluxes produced by the fishes during

185 the 24 hour period were calculated by subtraction of inlet fluxes from outlet fluxes.

186 Temperature, oxygen, $\mathrm{pH}$ and redox were also controlled with a Consort multi-parameter 187 analyser.

189 The "nutritional" method

190 Fish farm effluent production was calculated with the nutrient balance model developed by 191 Papatryphon et al. (2005). This model is based on feed utilisation by the fish. Waste fluxes 
192 are calculated by removing the part retained by the fish (biomass production and body

193 composition), from the part ingested by the fish.

194 Total effluents include solid and dissolved effluents, with solid effluents as the undigested

195 part of the feed (calculated with the nutrient digestibility coefficients (Guillaume et al.,

196 1999)), and dissolved effluents as the rest. The total-SS are calculated by adding the faecal

197 SS, equivalent to the non digested feed (proteins, lipids, carbohydrates, ash and fibres) and the

198 SS from uneaten feed. In this method, the following equations are used to calculate $\mathrm{N}, \mathrm{P}$ and

199 SS waste production:

200

201

202

(1) Total nitrogen $=$ solid nitrogen + dissolved nitrogen

Solid N = Faecal N + Uneaten N

With $\mathrm{BN}=$ Whole fish body $\mathrm{N}$ content $=0.0256-0.0272 \mathrm{~g} / \mathrm{g}$ of body weight (Papatryphon et al, 2005); FCR $=$ Feed Conversion Ratio. The dissolved $\mathrm{NH}_{4} \mathrm{~N}$ is calculated with an $80 \%$ coefficient corresponding to the proportion of $\mathrm{NH}_{4} \mathrm{~N}$ in total dissolved $\mathrm{N}$ excretion

212 (Papatryphon et al, 2005).

213 Similar equations with appropriate coefficients are used to evaluate $\mathrm{P}$ wastes: the proportion

214 of phosphorus in feed composition and the whole fish body P content of $0.004 \mathrm{~g} / \mathrm{g}$ of body 215 weight (Papatryphon et al, 2005). 
217

218

219

220

221

222

223

224

225

226

227

228

229

230

231

232

233

234

235

236

237

238

239

240

\section{(2) Total SS = faecal SS + uneaten feed SS}

Faecal SS $=$ Non digested proteins + Non digested lipids + Non digested carbohydrates + Non digested ash + Non digested fibres $=\left[(\mathrm{DF}-(\mathrm{DF} * \% \mathrm{UF})] * \sum[\%\right.$ nutriment $\mathrm{x}(100-\mathrm{DC}) \%]$

Uneaten feed $\mathbf{S S}=(\mathrm{DF} * \% \mathrm{UF}) *(\%$ dry matter in feed $)$

The digestibility coefficients (DC) were those proposed by Papatryphon et al., 2005 (table I); protein and lipid digestibility coefficients were compared to the digestibility coefficient measured by the manufacturer.

Fish were fed twice a day around $1 \%$ of the standing stock per day, with two different feed origins according to the fish size. The average feed composition is presented on table I. Fish were fed partly automatically, partly manually, up to satiety. The daily feed quantity distributed manually was determined from feeding tables by a computerised distribution system. The complementary quantity distributed manually up to satiety was also registered. This feeding method allowed avoiding uneaten feed. Tank biomass was evaluated from the biometrics every other week (average weight on 50 fish, for each batch) and enabled calculation of the FCR. Body nutrient contents were set on $26 \mathrm{~g} \mathrm{~N} . \mathrm{kg}^{-1}$ of body weight and 4 g P. kg-1 of body weight (Papatryphon et al., 2005).

\section{Results}

Daily feed rate and tank biomass were stable during the studied period. The biological data are presented in table II. The water flow rate of the whole farm fluctuated around $1336.7 \pm$ $210.81 . \mathrm{s}^{-1}$ (average daily flow rates of $820,840,1030$ and $8571 . \mathrm{s}^{-1}$ on sector 1 , during the four $24 \mathrm{~h}$ periods respectively, and 400, 370 and $5501 . \mathrm{s}^{-1}$ on sector 2 , during the three $24 \mathrm{~h}$ periods). 168 samples were treated. 
241 The daily waste fluxes of the farm, predicted with the nutritional method, the CEMAGREF

242 method and measured with the hydrobiological method are presented in table III, with

243 corresponding values expressed as fluxes per $\mathrm{kg}$ feed. These data correspond to the waste

244 produced by a standing stock of 132 tonnes of fish (average value during the studied period).

245 The daily average flux of total-N, measured using the hydrobiological method is $54.1 \pm 10$

$246 \mathrm{~kg} \cdot \mathrm{d}^{-1}$, when the predicted value is $59.82 \pm 6.01 \mathrm{~kg} \cdot \mathrm{d}^{-1}$. The measured daily flux of total-P is

$247 \quad 13.6 \pm 3.5 \mathrm{~kg} \cdot \mathrm{d}^{-1}$, almost twice the predicted value: $6.33 \pm 0.61 \mathrm{~kg} \cdot \mathrm{d}^{-1}$. The measured daily

248 flux of SS is $317.8 \pm 165.7 \mathrm{~kg} . \mathrm{d}^{-1}$ compared to a predicted value of $206.48 \pm 20.67 \mathrm{~kg} . \mathrm{d}^{-1}$. The

249 measured fluxes of particulate-N, $\mathrm{NH}_{4}-\mathrm{N}$ and urea-N are respectively $11.8 \pm 3.4,31.6 \pm 7.5$

250 and $10.7 \pm 2.5 \mathrm{~kg} \cdot \mathrm{d}^{-1}$ and the particulate $-\mathrm{P}$ and $\mathrm{PO}_{4}-\mathrm{P}$ fluxes produced by the fish are $9.6 \pm 3.6$

251 and $4.0 \pm 0.2 \mathrm{~kg} \cdot \mathrm{d}^{-1}$ (table III).

252 Using the CEMAGREF method (Fauré, 1983), $\mathrm{NH}_{4}-\mathrm{N}$, TP and SS fluxes of the farm are 36.4

$253 \pm 3.7,6.7 \pm 0.7$, and $136.3 \pm 14.1 \mathrm{~kg} . \mathrm{d}^{-1}$ respectively (table III).

254 Variance of the predicted and measured fluxes represents the variability of the fluxes between

255 each 24 hour period. The figure 2 presents a comparison between predicted and measured

256 fluxes.

257 Figures 3 - 5 show the relation between measured and predicted TN, TP and SS. The

258 measured and predicted TN values are well correlated with $\mathrm{r}^{2}=0.88$ ) whereas the correlation

259 coefficients between measured and predicted TP and SS values are weaker $(0.53$ and 0.48

260 respectively).

261 The hydrobiological method provides detailed information on the different forms of nitrogen

262 and phosphorous fluxes; $21 \%$ of nitrogen wastes are in the particulate form, $59 \%$ are $\mathrm{NH}_{4}-\mathrm{N}$

263 and $20 \%$ urea-N. $68.8 \%$ of the phosphorous wastes are in the particulate form and $31.2 \%$ are

264 dissolved $\mathrm{PO}_{4}-\mathrm{P}$. 
265 Concerning the daily fluctuations, $\mathrm{NH}_{4}-\mathrm{N}$ flux profiles (figure 6) show higher values during

266 the day and decrease in the night. In spite of a slight $\mathrm{NH}_{4}-\mathrm{N}$ increase 4 to 6 hours after the

267 morning feed distribution, the two daily feed distributions seem to reduce the postprandial

268 excretion peak. SS daily fluxes show higher fluctuations (figure 7). There is a time lag

269 between $\mathrm{NH}_{4}-\mathrm{N}$ and $\mathrm{SS}$ fluxes: $\mathrm{SS}$ transit seems to be slower than excretion. The

270 concentrations of other substances are lower and more stable during the day.

271

\section{Discussion and conclusion}

273 The CEMAGREF method gives lower SS value than the nutritional method and the measured

274 value (Table III and figure 2). This can be explained by excessive variation coefficients of the

275 results of this model, which is not statistically acceptable for the SS (Jatteau, 1999), and by

276 important daily SS fluctuations (figure 7). The predicted daily flux of total-P calculated using

277 the nutritional method is quite similar to the CEMAGREF estimation and lower than the

278 measured value. The $\mathrm{NH}_{4}-\mathrm{N}$ fluxes calculated with the three methods are in the same order of

279 magnitude. Even if the CEMAGREF method gives consistent results, this method is only

280 based on the daily quantity of feed distributedand do not take into account the feed

281 composition or the digestibility coefficients, while they are currently drastically improved. In

282 fact, metabolic wastes can be minimised by modifying the digestibility, the energetic density

283 and friability of the feed ingredients (Cho and Bureau, 1997; Kaushik, 1998; Roque

284 d'Orbcastel and Blancheton, in press, 2006). MacMillan et al. (2003) attributed $40 \%$ of the P

285 effluent reduction of flow-through trout farms, during the past 15 years, to management

286 improvements, such as feeding practices, low-P (0.9\%) feed use and frequent tank cleanings

287 (quiescent zone management). 
289 In our study, the total annual waste production estimated with the nutritional method, 290 expressed per metric ton of fish standing stock, were $147.5 \mathrm{~kg}$ for solids, $40.8 \mathrm{~kg}$ for $\mathrm{N}$, and

$2918.7 \mathrm{~kg}$ for P, lower than those reported by Axler et al. (1997) and by Bureau et al. (2003) for 292 salmonid farms (table IV).

293 Concerning the comparison between the nutritional method and the hydrobiological method 294 results, predicted and measured $\mathrm{N}$ waste fluxes are quite similar: the predictions and 295 measurements are well correlated $\left(r^{2}=0.88\right)$, with predictions a bit higher than measurements. 296 For the TP and SS parameters, the predicted and measured fluxes are less correlated $\left(\mathrm{r}^{2}\right.$ of 2970.53 and 0.48 respectively), with measurements higher than predictions. The physical 298 properties of solid wastes, subject to decantation as well as re-suspension, can explain part of 299 the differences. According to Boujard et al. (1999) and Papatryphon et al. (2005), N, P and 300 SS are sometimes underestimated by the hydrobiological method because of sampling 301 difficulties and sample preservation difficulties, and sometimes overestimated, because of 302 solid re-suspension (due to fishing, tank cleaning or hydrology). They can also be under or 303 overestimated by the nutritional method, depending on the digestibility coefficients and the 304 precision of ingested feed quantities.

305 Boujard et al. (1999) compared the results of waste evaluation with the nutritional and the 306 hydrobiological methods (two consecutive $24 \mathrm{~h}$ periods, with samples taken every 2 hours, on 3074 rainbow trout tanks). They found a global balance of nitrogenous wastes of 50-65 g N.kg 308 feed $^{-1}$ and 9-16 $\mathrm{g} \mathrm{P} . \mathrm{kg}$ feed $^{-1}$ for the phosphorous corresponding value, a bit higher than those 309 found during the present study. In their study, they defined the waste as the fraction of the 310 nutrients which are not retained by the fish, including also the uneaten feed (Boujard, pers. 311 comm.). The lower quantities that we measured using the hydrobiological method $(38.5 \pm 7.1$

312 of total- $\mathrm{N} \mathrm{g.kg}^{-1}$ feed and $9.7 \pm 2.5$ of total-P), could be explained by better feed management 313 on the Murgat farm which results in almost no uneaten feed. They shown also a good 
314 correlation between predicted and measured $\mathrm{N}$ values, with $\mathrm{r}^{2}=0.85$, higher than the

315 correlation factor for P values of 0.67 . According to the authors, the wastes measured with the

316 hydrobiological method were underestimated but comparable to the calculated values. They

317 attributed this underestimation to the settable characteristic of the suspended solids.

318 Papatryphon et al. (2005) compared the predicted values with $\mathrm{NH}_{4}^{+}$, $\mathrm{TP}$ and SS

319 concentrations measurements in the recipient river. They found waste prediction values well

320 correlated with the measured values, but the trend was an overestimation of predicted $\mathrm{NH}_{4}{ }^{+}$

321 and $\mathrm{P}$ values, that the authors explained by a probable degradation of $\mathrm{NH}_{4}{ }^{+}$in the samples

322 through nitrification processes. Some observed concentrations in SS were higher than

323 predictions, certainly due to the highly variable solid transport in aquaculture raceways (solids

324 decantation or re-suspension), which depends on the farm management and/or environmental

325 variability such as high flow rate. Maillard et al. (2005) observed higher TSS concentrations

326 during harvesting and feeding events (fish agitation) of different raceway system trout farms.

327

328 Both methods present drawbacks and advantages. The hydrobiological method is interesting

329 because it gives details on the different forms of $\mathrm{N}$ and $\mathrm{P}$ in the wastes (Boujard et al., 1999),

330 The results obtained in this study are comparable to those of previous studies: (Braaten, 1991;

331 Heinen et al., 1996; True et al., 2004) reported that over $85 \%$ of $\mathrm{N}$ was in dissolved form and

$33240-85 \%$ of $\mathrm{P}$ in solid form. Boujard et al. (1999) found that for $1 \mathrm{~kg}$ of dry feed (80-93 $\mathrm{g}$ of $\mathrm{N}$

333 and 12-21 $\mathrm{g}$ of $\mathrm{P}$ ) similar results for the $\mathrm{N}$ waste proportions (73\% of the nitrogen was

334 released, with $78 \%$ in $\mathrm{NH}_{4}-\mathrm{N}$ form) but opposite for the $\mathrm{P}$ wastes (87\% of the phosphorous

335 was released with $60 \%$ in dissolved form (mainly $\left.\mathrm{PO}_{4}-\mathrm{P}\right)$ ).

336 Using the hydrobiological method, we observed important daily $\mathrm{NH}_{4}-\mathrm{N}$ and $\mathrm{SS}$ fluxes

337 fluctuations (figure 8). In fact, fish farm wastes are highly fluctuating: daily variations

338 depending on feeding time and farm management (fishing, sorting...); annual variations 
339 depending on the fish biomass and distributed feed. For example, $\mathrm{NH}_{4}$ waste increases after

340 the feeding time, with a maximum around 6 hours after feeding, depending on species, feed

341 and feeding ratio and feeding several times a day contributes to decrease the waste daily

342 fluctuation (Dosdat et al., 1996; Jatteau, 1999). SS fluxes increase during the feeding period

343 because of fish motion and may also increase after digestion (after Guillaume et al., 1999,

344 ingested feed stays in the gut of 250-500g fishes during about 10 hours after ingestion).

345 Representative samples of the waste produced by the farm cannot be obtained if the number

346 of samples is decreased (Boujard et al., 1999; Cho and Bureau, 1997; Jatteau, 1999). Several

347 sampling periods have to be implemented simultaneously in the inlet and outlet of the farm in

348 order to get representative results. Sampling must be done carefully, especially because of the

349 solid matter properties. The AFNOR-NFT90-105 recommends a sample of a minimum

350 volume of $500 \mathrm{ml}$ (for fresh water). The samples have to be preserved because of the

351 possibility of nutrient transformation through leaching and bacterial activity.

352 For the hydrobiological method, the main difficulty is the water flow rate measurement, a key

353 point for the flux evaluation but difficult even with a precision equipment. From one tank to

354 another, even if the geometry is the same, the measured flow rate varies by $20 \%$. From one

355 day to another, the variation of the flow rate measurement could be around $35 \%$. The

356 difficulty in evaluating the water flow rate makes current waste control validity questionable.

357 Environmental monitoring is based on the use of indicators, such as the maximum SS, BOD,

$358 \mathrm{NH}_{4}$ concentrations in the recipient ecosystem. As fluxes are calculated with concentration

359 and flow rate, it seems to be difficult to properly control the correlation between the measured

360 and the predicted values at the farm outlet (with their own uncertainties) as recorded by the

361 farmer in the environmental assessment.

362 The hydrobiological method appears to be too heavy and costly for regular use as part of the 363 waste quantification and self monitoring processes required under the ICPE legislation. 
364 In comparison, the nutritional method is easier and quicker, and a rather inexpensive way to

365 predict fish waste production. Using the theoretical digestibility coefficients (Papatryphon et

$366 a l ., 2005)$ and feed composition given by the manufacturer, or the measured digestibility

367 coefficients (for proteins and lipids) and feed composition, the nutritional method gave

368 different solid waste evaluation. With the theoretical protein, lipid and carbohydrate

369 coefficients and theoretical feed composition, the SS predicted emissions are 88.5 tons / year

370 whereas with measured coefficients, the model gives 69.3 tons / year. So the feed composition

371 and the digestibility coefficients used in the model can lead to more than $20 \%$ variation in the

372 solid waste evaluation.

373 Even if the hydrobiological and nutritional methods do not allow one to precisely anticipate

374 waste production, both provide interesting orders of magnitude; the nutritional method is the

375 simplest for the fish farmers to evaluate the waste produced by their farm, although it requires

376 precise information (especially on feed composition, ingested feed quantity and digestibility

377 coefficients are available).

378

379 If it is established that waste emissions can be reduced at the fish level (Cho and Bureau,

380 1997; Kaushik, 1998; Roque d'Orbcastel and Blancheton, 2006; MacMillan et al. 2003),

381 waste also has to be reduced at the system level through the use of well designed waste

382 treatment systems. The design of the treatment systems also requires good knowledge of the

383 waste production process especially because the economic feasibility of aquaculture waste

384 treatment has not yet been demonstrated in most of the situations.

385

386 Acknowledgements

387 We would like to extend our sincere thanks to Vincent and Laurent Murgat and all the farm

388 team for their collaboration their permanent kindness and availability and the Palavas team 
389 for their support, especially Gilbert Dutto for his interesting technical comments. We also

390 acknowledge Professor Puy Lim for reviewing this article and for its helpful suggestions. 


\section{References}

Axler, R.P., Tikkanen, C., Henneck, J., Schuldt, J., and McDonald, M.E., 1997. Characteristics of effluent and sludge from two commercial rainbow trout farms in Minnesota. The Progressive Fish Culturist, 59, 161-172.

Benschneider, K., and Robinson, R.J., 1952. A new spectrophotometric determination of nitrite in seawater. J. Mar. Res., 11, 87-96.

Bergheim, A., and Brinker, A., 2003. Effluent treatment for flow through systems and European environmental regulations. Aquac. Eng., 27, 61-77.

Boujard, T., Vallée, F., and Vachot, C., 1999. Evaluation des rejets d'origine nutritionnelle de truiticultures par la méthode des bilans, comparaison avec les flux sortants. Dossier de l'environnement, INRA (Eds), 26, 32-35.

Braaten, B., 1991. Impact of pollution from aquaculture in six Nordic countries. Release of nutrients, effects, and wastewater treatment. In: De Pauw, N., Joyce, J. N. (Eds), Aquaculture and the Environment. European Aquaculture Society Publication 16, Ghent, Belgium, 79-101.

Bureau, D.P., Gunther, S.J., Cho, C.Y., 2003. Chemical composition and preliminary theoretical estimates of waste outputs of rainbow trout reared in commercial cage culture operations in Ontario. N. Am. J. Aquacult., 65, 33-38.

Cho, C.Y., 1993. Digestibility of feedstuffs as a major factor in aquaculture waste management. In: Fish Nutrition in Practice, S.J., Kaushik and P., Luquet (Eds), INRA, Paris, 61, 365-374.

Cho, C.Y., and Bureau, D.P., 1997. Reduction of waste output from salmonid aquaculture through feeds and feedings. The Progressive Fish Culturist, 59, 155-160. 
Cho, C.Y., and Bureau, D.P., 1998. Development of bioenergetic models and the Fish-PrFEQ software to estimate production, feeding ration and waste output in aquaculture. IN Proc. of the 3rd International Symposium on Nutritional Strategies and Management of Aquaculture Waste. Aquat. Living Resour., 11, 199-210.

Cho, C.Y., Hynes, J.D., Wood, K.R., and Yoshida, H.K., 1991. Quantification of fish culture wastes by biological (nutritional) and chemical (limnological) methods; the development of high nutrient dense (HND) diets. Nutritional Strategies and Aquaculture Waste. Proceedings of the 1st International Symposium on Nutritional Strategies in Management of Aquaculture Waste, Guelph, Ontario, Canada. In: Cowey, C.B., and Cho, C.Y., (Eds).

Cho, C.Y., Hynes, J.D., Wood, K.R., and Yoshida, H.K., 1994. Development of high nutrientdense, low pollution diets and prediction of aquaculture wastes using biological approaches. Aquaculture, 124, 293-305.

Company, R., Calduch-giner, J.A., Perez-sanchez, J., and Kaushik, S.J., 1999. Protein sparing effect of lipids in common dentex (Dentex Dentex): A comparative study with sea bream (Sparus aurata) and sea bass (Dicentrarchus Labrax). Aquat. Living Resour., 12, 23-30.

Dosdat, A., 1992a. L'excrétion chez les poissons téléostéens I. Azote. Piscic. Fr., 108, 25-37.

Dosdat, A., 1992b. L'excrétion chez les poissons téléostéens II. Le Phosphore. Piscic. Fr., $109,1828$.

Dosdat, A., Servais, F, Métailler, R., Huelvan, C., and Desbruyères, E., 1996. Comparison of nitrogenous losses in five teleost fish species. Aquaculture, 141, 107-127.

Dosdat, A., 1999. Rappels de physiologie et de métabolisme. In: Aquaculture et environnement, tome 1, aspects techniques et économiques, Jean Petit (ed.). INRA, Paris, 6974. 
Fauré, A., 1983. Salmoniculture et Environnement, Vol 1. Evaluation de la pollution rejetée par les salmonicultures intensives. CEMAGREF, Bordeaux, France, Etude n ${ }^{\circ} 6,71 \mathrm{pp}$.

Fernandes, T.F., Miller, K.L., and Reard, P.A., 2000. Monitoring and regulation of marine aquaculture in Europe. J. Appl. Ichthyol., 16, 138-143.

Guillaume, J., Kaushik, S., Bergot, P., and Métailler, R., 1999. Bases de la nutrition des animaux aquatiques: physiologie digestive et digestibilité des nutriments. Nutrition et alimentation des poissons et crustacés. Éditions INRA-IFREMER, 489 pp, 71-75.

Heinen, J.M., Hankins, J.A., and Adler, P.R., 1996. Water quality and waste production in a recirculating trout-culture system with feeding of a higher energy or a lower energy diet. Aquac. Res., 27, 699-710.

Hennessy, M.M., Wilson, L., Struthers, W., and Kelly, L. A., 1996. Waste loadings from two freshwater atlantic salmon juvenile farms in Scotland. Water, Air and soil pollution, 86, 23549.

Huhta, C., and Ward, C.J., 2003. Flow Measurements using an Upward-Looking ArgonautSW Doppler Current Meter: in IEEE/OES Seventh Working Conference on Current Measurement Technology, San Diego, CA, March 10-13, 2003, Proceedings.

Jatteau, P., 1999. Quantification des flux polluants. Aquaculture et environnement, tome 1, aspects techniques et économiques, Jean Petit (éd.). INRA, Paris, pp 74-87.

Kaushik, S.J., 1980. Influence of nutritional status on the daily patterns of nitrogen excretion in the carp (Cyprinus carpio L.) and the rainbow trout (Salmo gairdneri R.). Reprod. Nutr. Develop., 20 (6), p 1751.

Kaushik, S.J., 1998 . Nutritional bioenergetics and estimation of waste production in non salmonids. Aquat. Living Resour., 11, 211-217. 
Kelly, L.A., Bergheim, A., and Hennessy, M.M., 1994. Predicting output of ammonium from fish farms. Wat. Res., 28 (6), pp 1403-1405.

Lemarié, G., Martin, J.L.M, Dutto, G., and Garidou, C., 1998. Nitrogenous and phosphorous waste production in a flow-through land-based farm of European seabass (Dicentrarchus labrax). Aquat. Living Resour., 11, 247-254.

Liao, P., 1970. Pollution potential of salmonids fish hatcheries. Water sewage works, 117, 291-297.

Liao, P., and Mayo, R., 1974. Intensified fish culture combining water reconditioning with pollution abatement. Aquaculture, 3, 61-85.

MacMillan, J.R., Huddleston, T., Woolley, M., and Fothergill, K., 2003. Best management practice development to minimize environmental impact from large flow-through trout farms. Aquaculture, 226, 91-99.

Maillard, V.M., Boardman, G.D., Nyland, J.E., and Kuhn, D.D., 2005. Water quality and sludge characterisation at raceway-system trout farms. Aquac. Eng., 33, 271-284.

Maroni, K., 2000. Monitoring and regulation of marine aquaculture in Norway. J. Appl. Ichthyol., 16, 192-195

Papatryphon, E., Petit, J., Hayo, V., Kaushik, S.J., and Claver, K., 2005. Nutrient-balance modelling as a tool for environmental management in aquaculture: The case of trout farming in France. Env. Managem., 35 (2), 161-174.

Pedersen, P.B., 1999. Monitoring and regulation of marine aquaculture in Denmark. J. Appl. Ichthyol., 16, 144-147. 
Roque d'orbcastel E., and Blancheton, J.P., 2006. The wastes from marine fish production systems : characterization, minimization, treatment and valorization. World aquaculture, 37, $3,28-35,70$.

Solorzano, L., 1969. Determination of ammonia in natural waters by the phenol-hypochlorite method. Limnol. Oceanogr., 14, 799-801.

Tarazona, J.V., Ortiz, J.A., Carbello, M., and Munoz, M.J., 1993. Pollution generated by fish farms. A systems dynamics model. Fresenius Environmental Bulletin, 2, 84-89.

True, B., Johnson, W., and Chen, S., 2004. Reducing phosphorous discharge from flowthrough aquaculture I: facility and effluent characterisation. Aquac. Eng., 32, 129-144.

Wood, E.D., Armstrong, F.A.J., and Richards, F.A., 1967. Determination of nitrate in sea water by cadmium cooper reduction to nitrite. J. Mar. Biol., 47, 23-31 
Table I. fish extruded feed composition (\%), theoretical nutrient digestibility coefficients (DC) (from Papatryphon et al., 2005) and calculated digestibility coefficients (\%) (Moutounet, pers. comm.)

\begin{tabular}{cccc}
\hline & Mean feed composition (\%) Theoretical DC (\%) Calculated DC (\%) \\
\hline Moisture & 8 & & \\
Protein & 45 & 90 & 93 \\
Lipids & 27 & 60 & 96 \\
Carbohydrate & 10.1 & 50 & 75 \\
Ash & 6.7 & 0 & \\
Fibre & 1.4 & 50 & \\
Phosphorus & 0.9 & \\
Energy (MJ.kg &
\end{tabular}


Table II. Biomass in tanks, daily feed quantities, average feeding rates and FCR of the farm during the different sampling series (last serie only includes the sector 1 results; sector 2 was not sampled because of too important fishing events)

\begin{tabular}{ccccc}
\hline Date & $\begin{array}{c}\text { Biomass } \\
(\mathrm{kg})\end{array}$ & $\begin{array}{c}\text { Daily feed } \\
\left(\mathrm{kg} . \mathrm{d}^{-1}\right)\end{array}$ & $\begin{array}{c}\text { Average feeding } \\
\text { Rate }(\%)\end{array}$ & $\begin{array}{c}\text { Average FCR } \\
\left({\left.\mathrm{kg} . \mathrm{kg}^{-1}\right)}^{-1}\right.\end{array}$ \\
\hline $25-26.01 .2006$ & 177449 & 1314 & 0.74 & 0.88 \\
$07-08.02 .2006$ & 174412 & 1333 & 0.76 & 0.87 \\
$22-23.02 .2006$ & 178571 & 1568 & 0.88 & 0.88 \\
$07-08.03 .2006$ & 130643 & 1012 & 0.84 & 0.77 \\
\hline
\end{tabular}


Table III. Daily waste production of the whole farm, predicted according to the nutritional method and measured in situ with the hydrobiological method, expressed in $\mathrm{kg} \cdot \mathrm{d}^{-1}$ and $\mathrm{g} \cdot \mathrm{kg}^{-1}$ feed delivered. $\mathrm{d}^{-1}$

\begin{tabular}{|c|c|c|c|c|c|}
\hline Parameter & $\begin{array}{c}\text { Measured } \\
\text { mean fluxes } \\
\left.\text { (kg.d } \mathrm{d}^{-1} \pm \text { S.D. }\right)\end{array}$ & $\begin{array}{l}\text { Predicted mean } \\
\quad \text { fluxes } \\
\left.\text { (kg.d } \mathrm{d}^{-1} \pm \text { S.D. }\right)\end{array}$ & $\begin{array}{c}\text { Cemagref } \\
\text { calculated } \\
\text { values }\left(\mathrm{kg} . \mathrm{d}^{-1} \pm\right. \\
\text { S.D.) }\end{array}$ & $\begin{array}{l}\text { Measured mean } \\
\text { fluxes } \\
\text { (g. } \mathrm{kg}^{-1} \text { feed.d } \\
{ }_{ \pm} \\
\pm \text {S.D. })\end{array}$ & $\begin{array}{l}\text { Predicted mean } \\
\text { fluxes } \\
\text { (g. kg }{ }^{-1} \text { feed. } \mathrm{d}^{-1} \pm \\
\text { S.D.) }\end{array}$ \\
\hline $\begin{array}{l}\text { Suspended } \\
\text { solids }\end{array}$ & $317.8 \pm 165.7$ & $206.5 \pm 20.7$ & 14.1 & $226.2 \pm 117.9$ & $147.0 \pm 0.2$ \\
\hline Total nitrogen & $54.1 \pm 10$ & $59.8 \pm 6.0$ & & $38.5 \pm 7.1$ & $42.6 \pm 0.4$ \\
\hline $\begin{array}{c}\text { Particulate } \\
\text { nitrogen }\end{array}$ & $11.8 \pm 3.4$ & $10.1 \pm 1.0$ & & $8.4 \pm 2.4$ & $7.2 \pm 0.0$ \\
\hline $\begin{array}{l}\text { Ammonia } \\
\text { nitrogen }\end{array}$ & $31.6 \pm 7.5$ & $39.7 \pm 4.0$ & $36.4 \pm 3.7$ & $22.5 \pm 5.3$ & $28.3 \pm 0.3$ \\
\hline Urea nitrogen & $10.7 \pm 2.5$ & - & 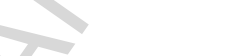 & $7.6 \pm 1.8$ & - \\
\hline $\begin{array}{c}\text { Total } \\
\text { phosphorus }\end{array}$ & $13.6 \pm 3.5$ & 6.3 & $6.7 \pm 0.7$ & $9.7 \pm 2.5$ & $4.5 \pm 0.1$ \\
\hline $\begin{array}{l}\text { Particulate } \\
\text { phosphorus }\end{array}$ & $9.6 \pm 3.6$ & & & $6.8 \pm 2.6$ & - \\
\hline $\begin{array}{c}\text { Orthophosphate- } \\
\text { P }\end{array}$ & $4.0 \pm 0.2$ & & & $2.8 \pm 0.1$ & - \\
\hline
\end{tabular}


Table IV. Total annual waste production of the farm calculated with the nutritional method, in comparison with values reported by Axler et al. (1997) and Bureau et al. (2003), expressed per metric ton of fish

\begin{tabular}{lccc}
\hline Parameter & $\begin{array}{c}\text { Calculated values } \\
\left(\mathrm{kg} . \text { ton }^{-1} \text { of fish }\right. \\
\text { produced })\end{array}$ & $\begin{array}{c}\text { Axler } \text { et al. (1997) } \\
\text { values }\left(\mathrm{kg} . \text { ton }^{-1} \text { of }\right. \\
\text { fish produced })\end{array}$ & $\begin{array}{c}\text { Bureau et al. (2003) } \\
\text { values (kg. ton }{ }^{-1} \text { of fish } \\
\text { produced })\end{array}$ \\
\hline Suspended solids & 147.5 & $289-839$ & $240-318$ \\
Total nitrogen & 40.8 & $47-87$ & $47-71$ \\
Total phosphorus & 8.7 & $4.8-18.7$ & $7.5-15.2$ \\
\hline
\end{tabular}




\section{Figure captions}

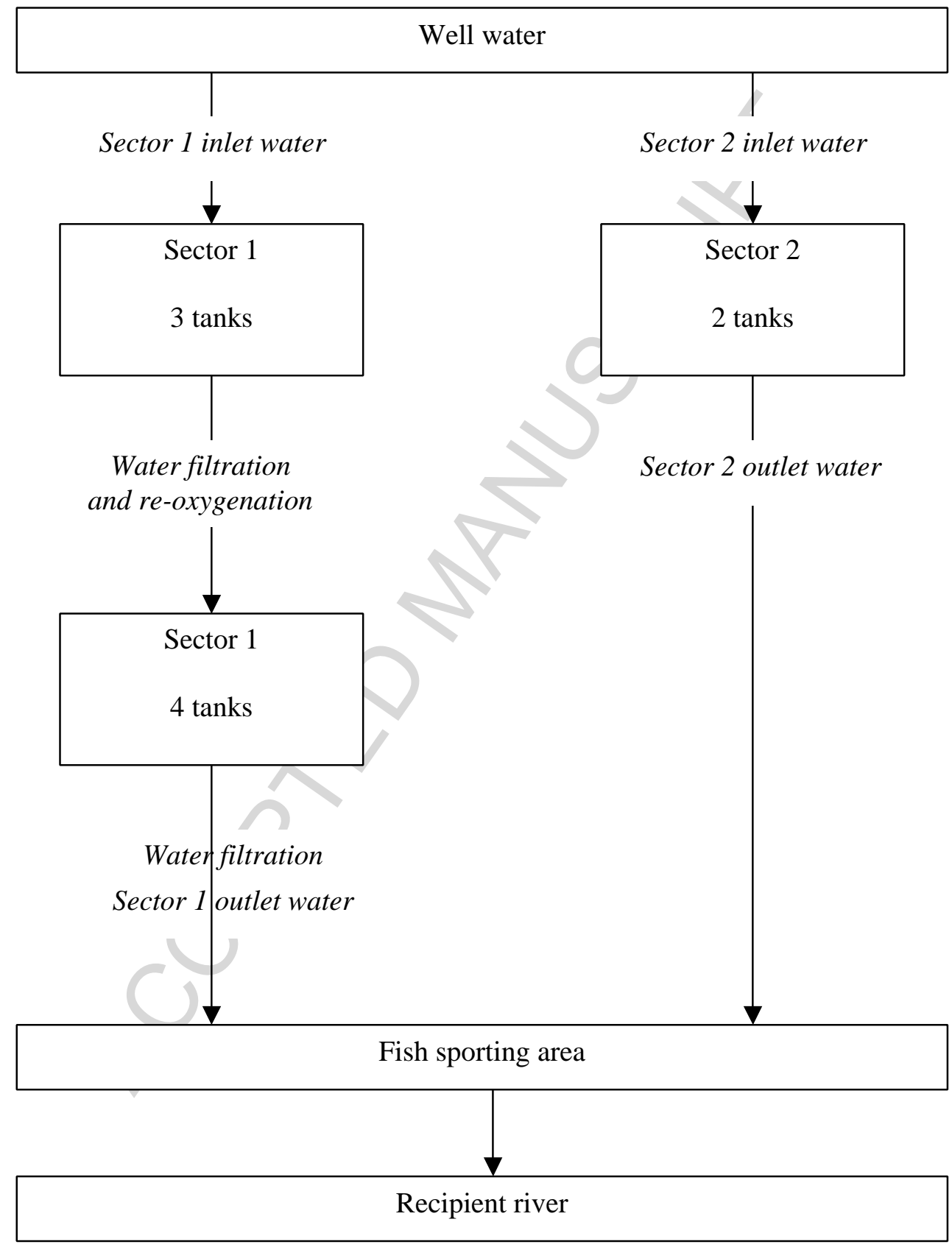

Figure 1. The growing sector of the farm, divided into two sectors: sector 1 composed of 7 concrete tanks with 4 species reared and sector 2 composed of 2 concrete tanks with only rainbow trout species. Each sector is fed by its own well water. 


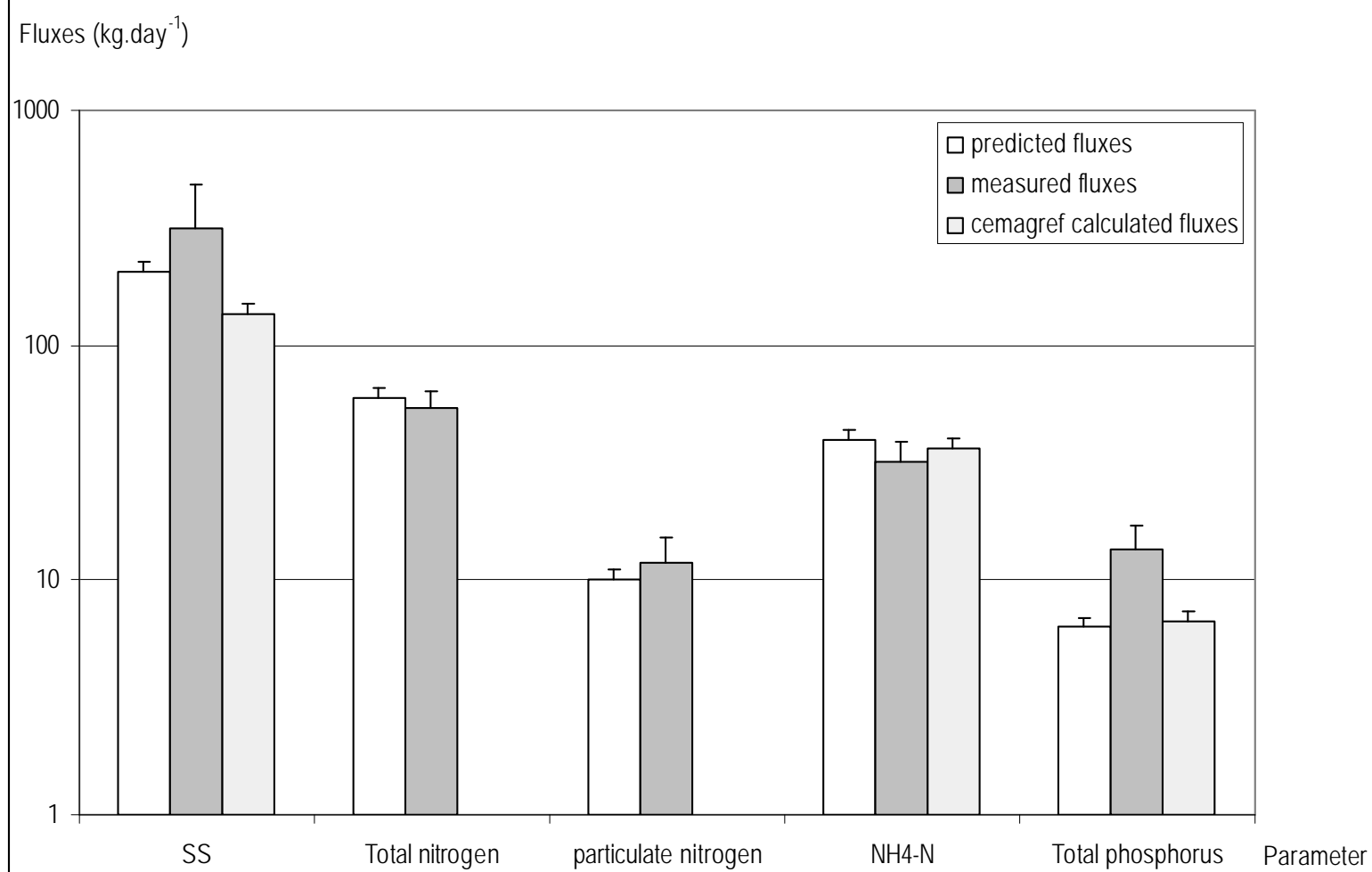

Figure 2. Predicted (nutritional method and CEMAGREF method) and measured fluxes of the farm, expressed in $\mathrm{kg}$ per day, with a logarithmic scale. 


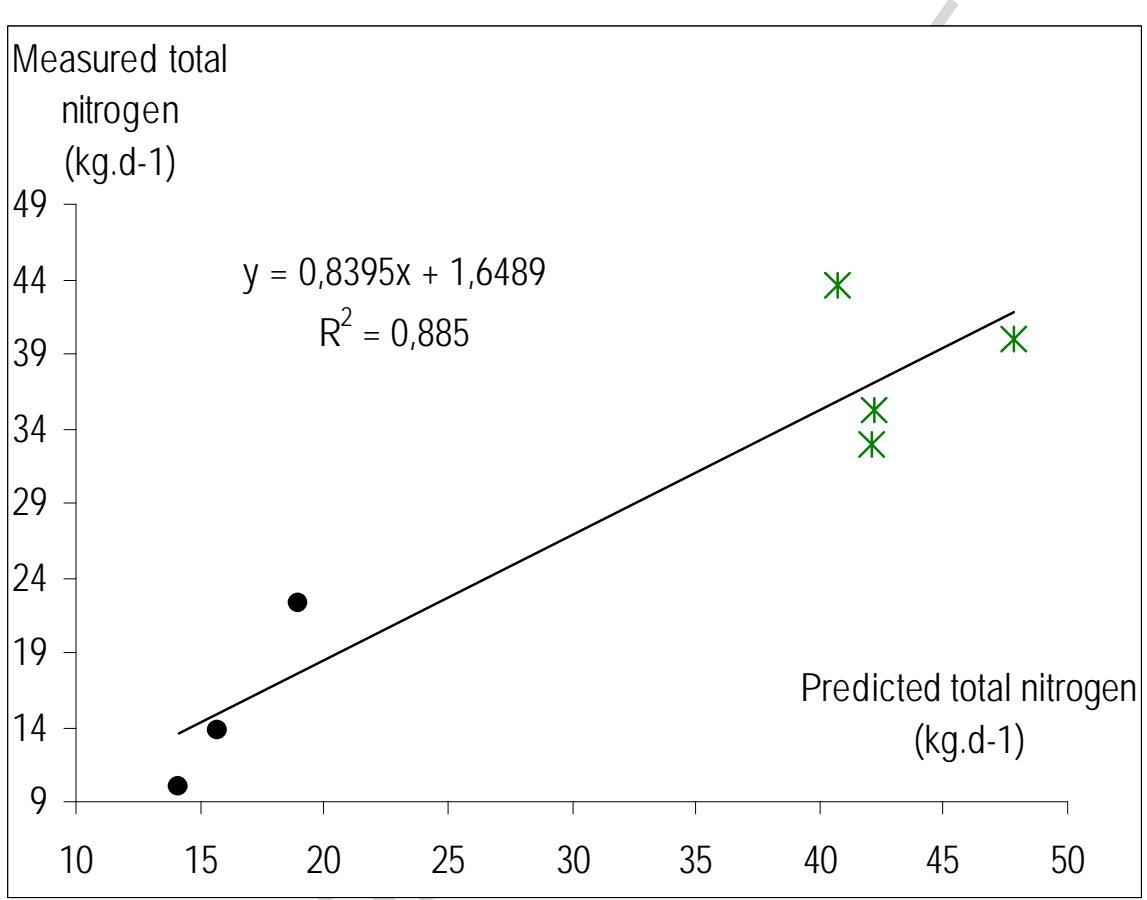

Figure 3. Comparison of the total-N measured values and the total-N predicted values, in the two different areas of the farm (sector 1 values are represented with green stars, sector 2 values with black points). The measured values are obtained from the hydrobiological method, the predicted values from the nutritional method. Total-N is the total-N flux produced by the farm during a day, expressed in $\mathrm{kg}$ per day. $\mathrm{R}^{2}$ is the correlation factor. 


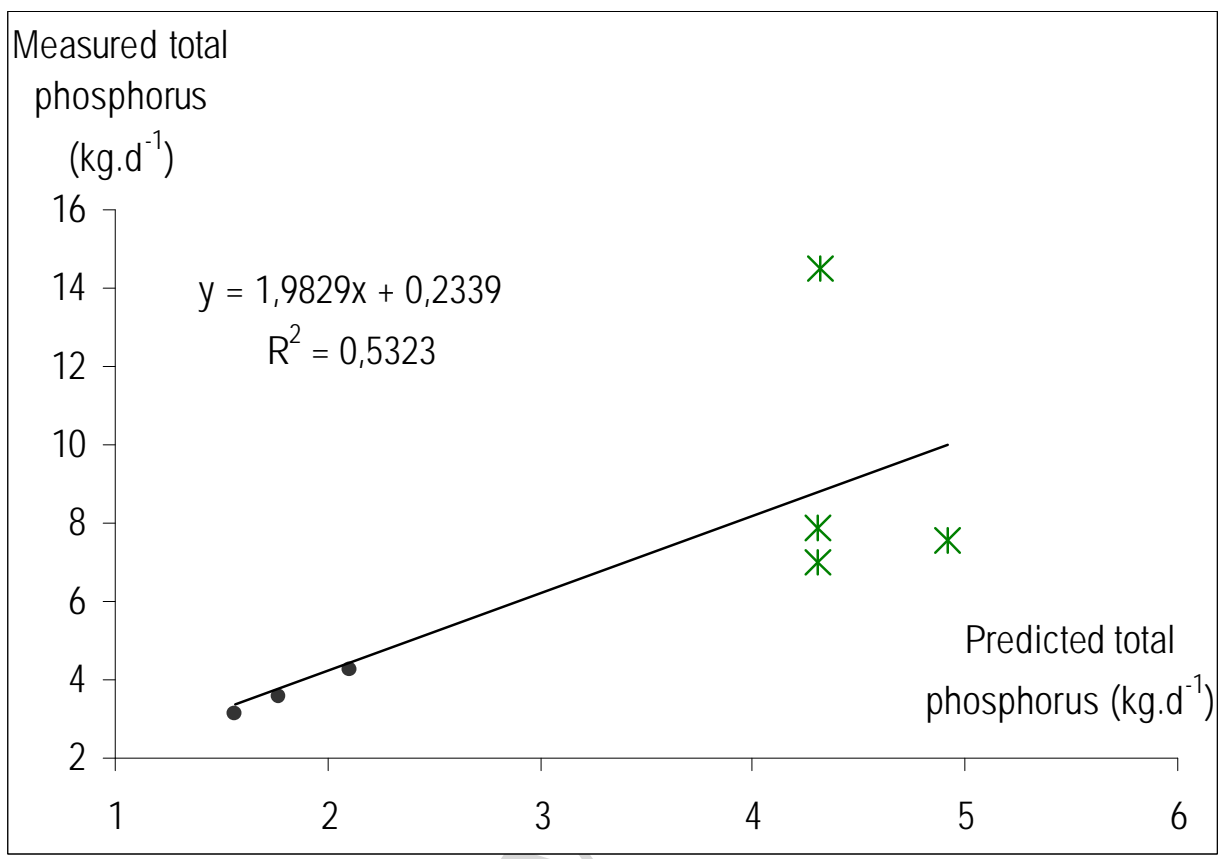

Figure 4. Comparison of the total-P measured values and the total-P predicted values, in the two different areas of the farm (sector 1 values are represented with green stars, sector 2 values with black points). The measured values are obtained with the hydrobiological method, the predicted values with the nutritional method. Total-P is the total-P flux produced by the farm during a day, expressed in $\mathrm{kg}$ per day. $\mathrm{R}^{2}$ is the correlation factor. 


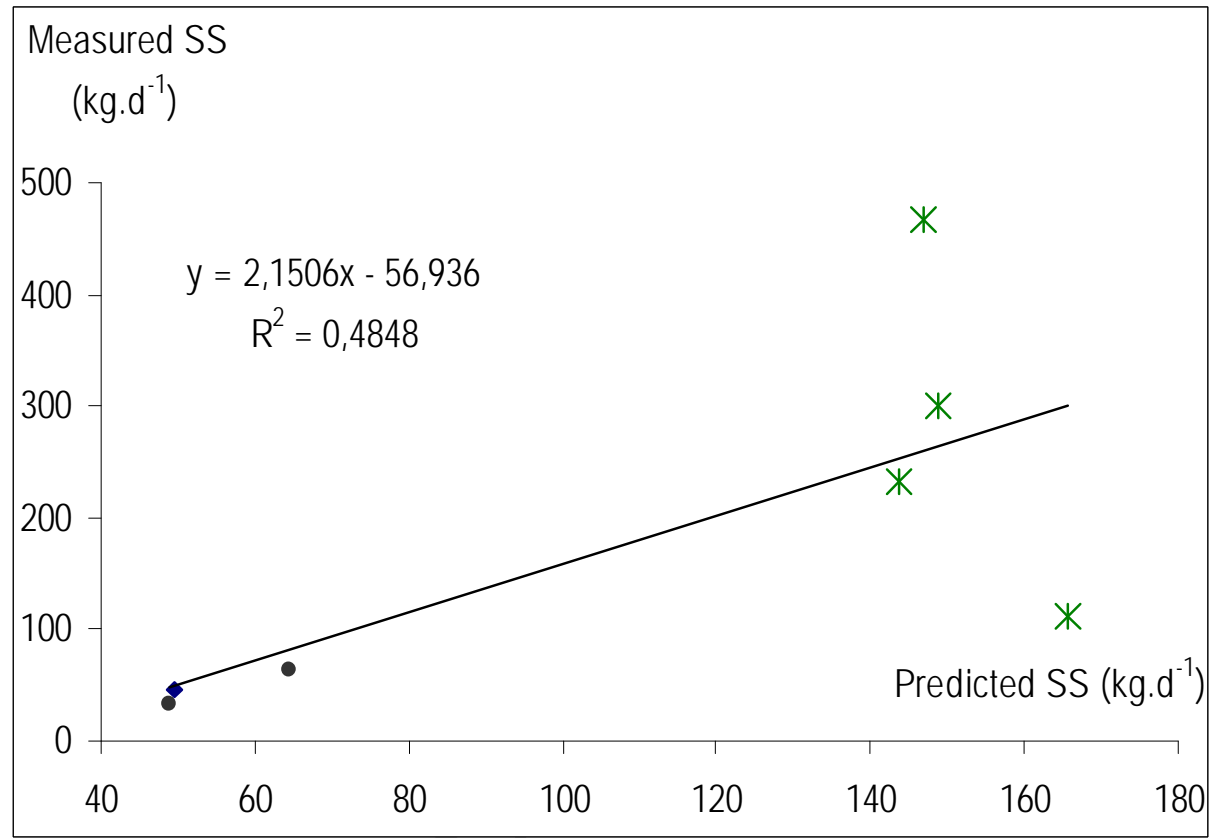

Figure 5. Comparison of the total suspended solid measured values and the total suspended solid predicted values, in the two different areas of the farm (sector 1 values are represented with green stars, sector 2 values with black points). The measured values are obtained with the hydrobiological method, the predicted values with the nutritional method. TSS is the total suspended solid flux produced by the farm during a day, expressed in $\mathrm{kg}$ per day. $\mathrm{R}^{2}$ is the correlation factor. 


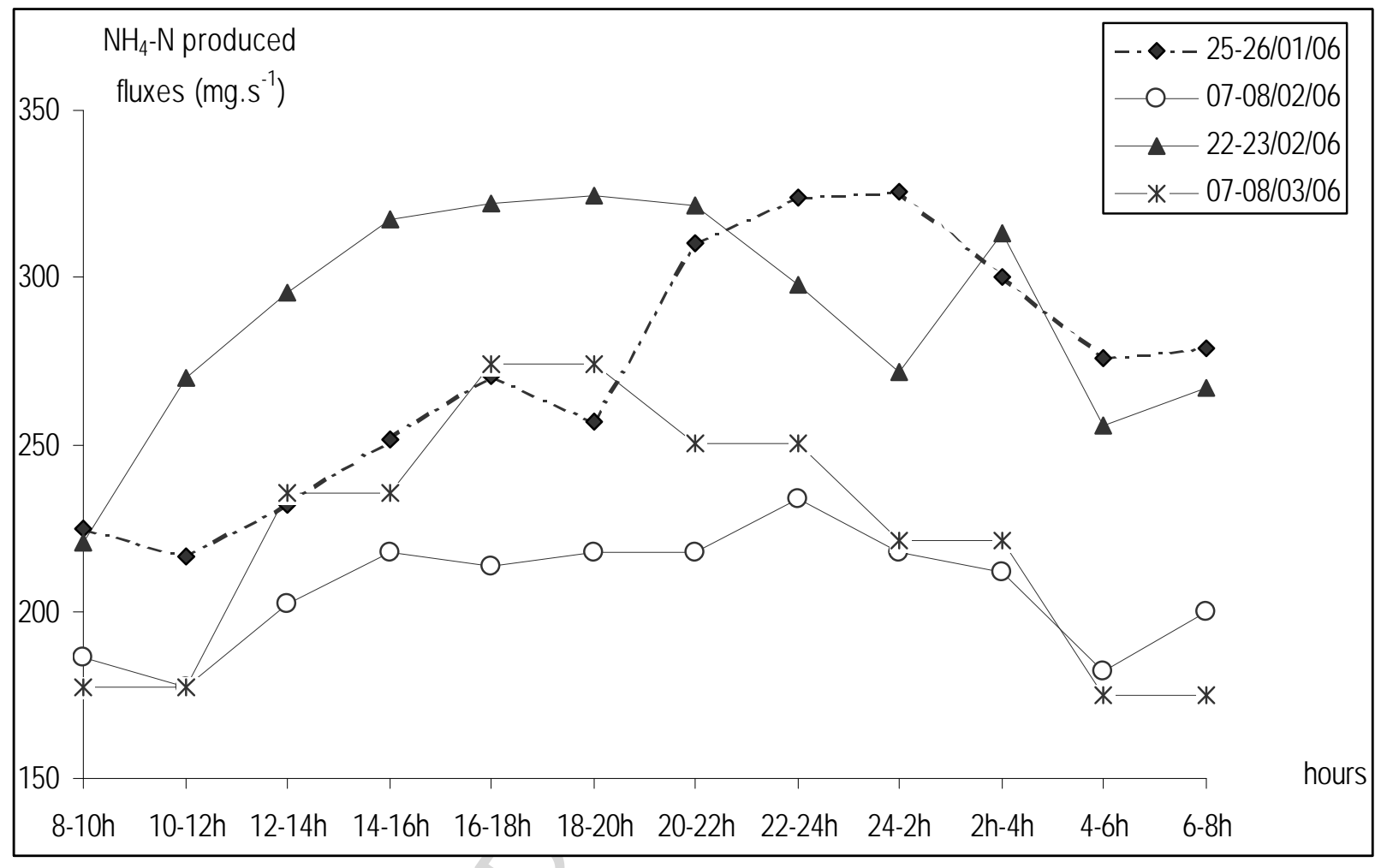

Figure 6. Daily fluctuations of the $\mathrm{NH}_{4}-\mathrm{N}$ produced by the farm (sectors 1 \& 2), for 3 different $24 \mathrm{~h}$ sampling periods (1: 25-26.01.2006; 2: 07-08.02.2006; 3: 22-23.02.2006) and produced by the sector 1 only for the last date (06-07.03.06). The $\mathrm{NH}_{4}-\mathrm{N}$ fluxes are expressed in $\mathrm{mg}$ per second. 


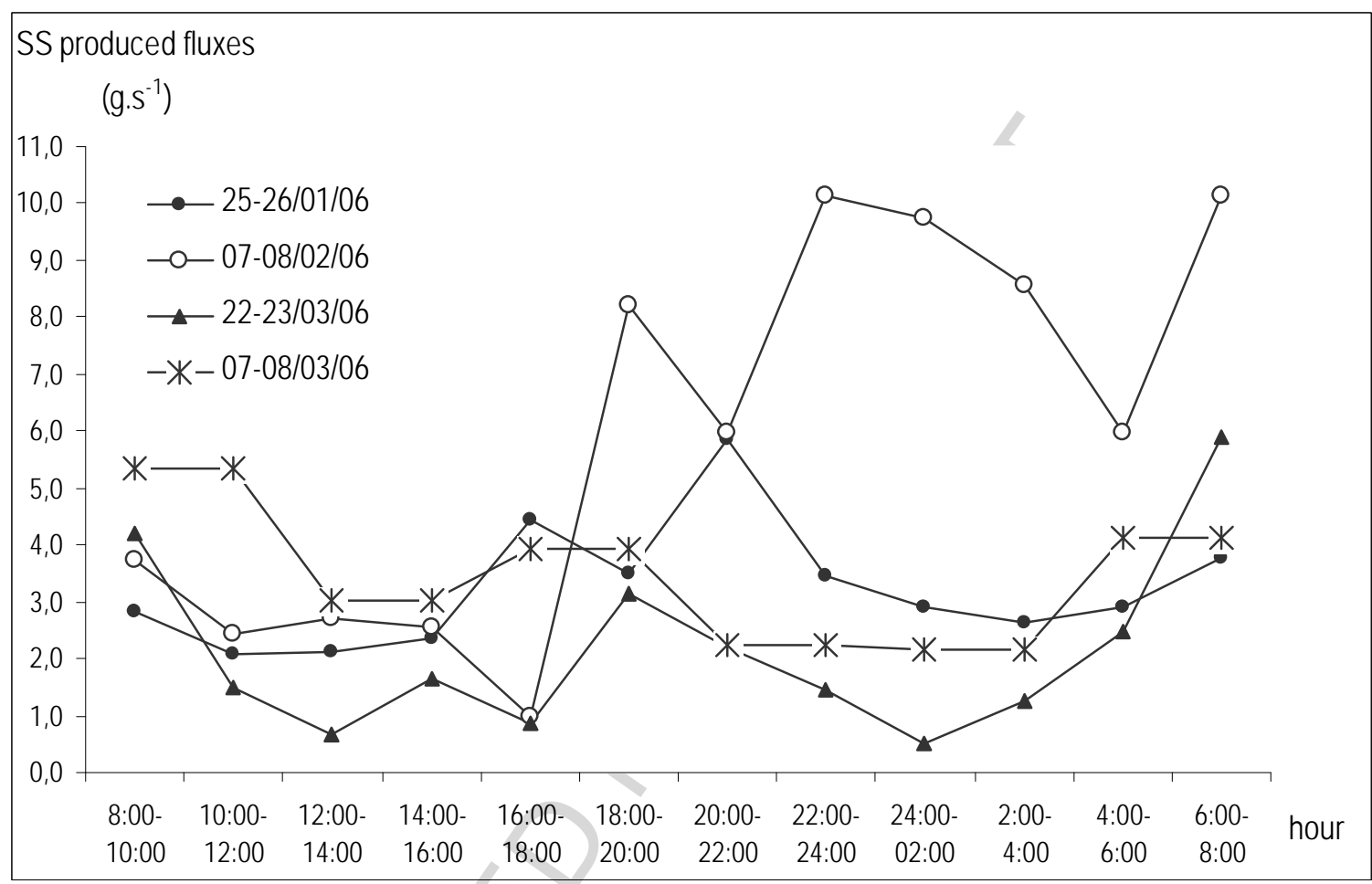

Figure 7. Daily fluctuations of the total suspended solids produced by the farm, for the first 3 24h sampling periods (1: 25-26.01.2006; 2: 07-08.02.2006; 3: 22-23.02.2006) and produced by the sector 1 for the last date (06-07.03.06). The TSS fluxes are expressed in $g$ per second. 


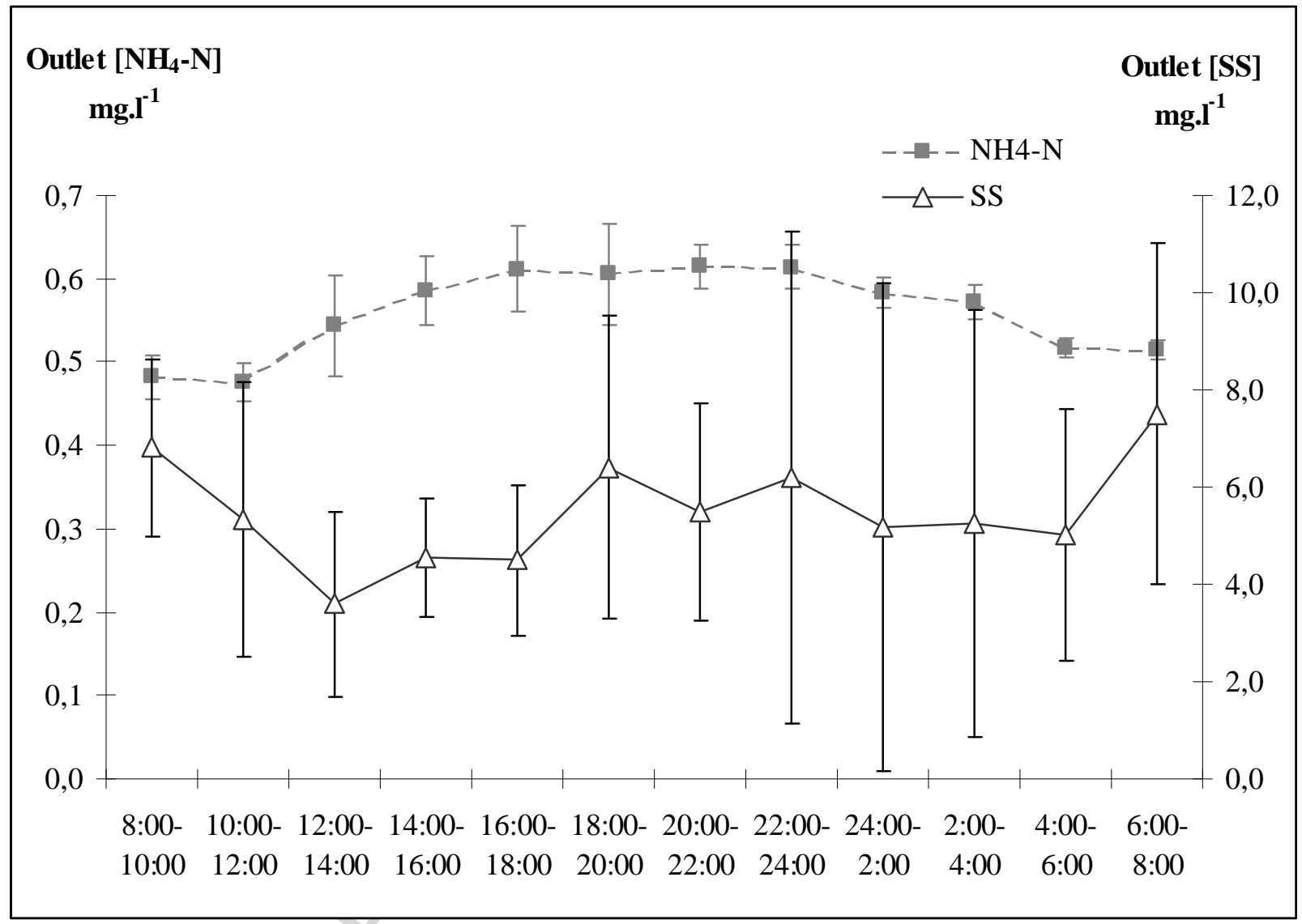

Figure 8. Averaged suspended solid and $\mathrm{NH}_{4}-\mathrm{N}$ outlet concentrations (with standard deviations), measured at the outlet point of the farm, during four different $24 \mathrm{~h}$ sampling periods. The concentrations are expressed in $\mathrm{mg}$ per litre. 


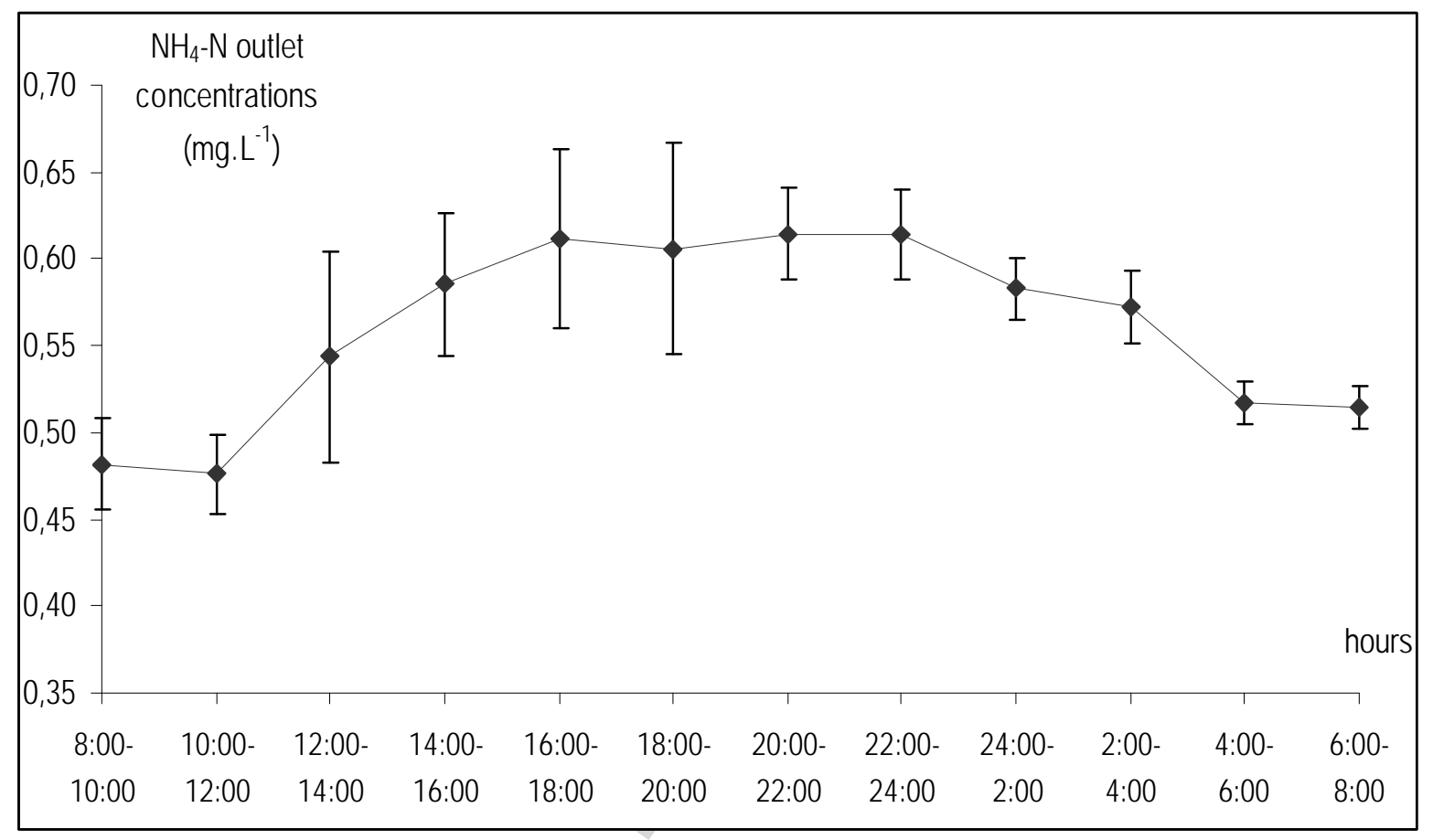

Figure 9. Averaged $\mathrm{NH}_{4}-\mathrm{N}$ outlet concentrations (with standard deviations), measured at the outlet point of the farm, during four different $24 \mathrm{~h}$ sampling periods. The concentrations are expressed in $\mathrm{mg}$ per litre. 